Acta Universitatis Nicolai Copernici • Pedagogika XLII/2/2021

Nauki Humanistyczno-Społeczne • Zeszyt 454

DOI: http://dx.doi.org/10.12775/AUNC_PED.2021.022

\author{
Wiesław Partyka \\ Instytut Pedagogiki \\ Wydział Nauk Społecznych \\ Katolicki Uniwersytet Lubelski Jana Pawła II \\ ORCID: 0000-0002-5595-2901
}

\title{
Marian Surdacki, Miłosierdzie czy opieka społeczna. Od starożytności do oświecenia,
}

Wyd. Towarzystwo Naukowe KUL, Lublin 2020, ss. 364.

\begin{abstract}
T Tistoria opieki społecznej i problematyka dobroczynności, tak — _w kontekście polskim, jak i europejskim (szczególnie włoskim), stała się głównym przedmiotem zainteresowań i badań prowadzonych od początku pracy naukowej prof. Mariana Surdackiego. Pewnym podsumowaniem jego dotychczasowych badań jest wydana w 2020 roku monografia Miłosierdzie czy opieka społeczna. Od starożytności do oświecenia. Dopełnia ona poprzednie opracowanie poświęcone tej problematyce Opieka społeczna $w$ Polsce do końca XVIII wieku (2015) o powszechny (europejski i nie tylko) obraz dziejów dobroczynności i opieki, a zarazem likwiduje panującą w polskiej literaturze naukowej lukę. Praca posiada przemyślaną kompozycję, przejrzysty układ i wartki, klarowny tok narracji. Składa się z dwóch części, posiadających nieco inny charakter. O ile część pierwsza, bardziej obszerna, oparta w dużej mierze na badaniach zagranicznych, szczególnie włoskich, Świat, stanowi nowość, to druga Polska, jest zwięzłym streszczeniem bardzo szczegółowych badań zamieszczonych w monografii dotyczącej opieki społecznej w Polsce. Dzięki temu otrzymujemy całościowe kompen-
\end{abstract}


dium wiedzy na temat dziejów dobroczynności w ujęciu powszechnym. Autor zastosował $\mathrm{w}$ pracy schemat problemowy, a w jego ramach niekiedy chronologiczny. Z wielką dbałością starał się, by poszczególne zagadnienia tematyczne ułożone były w logicznym ciągu czasowym, według zasady kolejności i następstwa.

$\mathrm{Na}$ tle dotychczasowej historiografii polskiej jest to opracowanie całkowicie pionierskie i nowatorskie. Ujmuje całokształt działalności instytucji opiekuńczych i innych pozainstytucjonalnych inicjatyw dobroczynnych podejmowanych przez środowiska kościelne, świeckie i państwowe na rzecz wszelkiej kategorii potrzebujących, w tym także opiekę medyczną. Autor śledzi i przedstawia radykalne zmiany w koncepcji dobroczynności, poczynając od antycznej Grecji i świata rzymskiego, poprzez bardzo przychylne biedakom średniowiecze, krytyczne w stosunku do nich czasy renesansu i reformacji, „wielkie zamknięcie" w XVII wieku, aż po czasy i prądy oświeceniowe, które przyniosły laicyzację dotychczasowej dobroczynności kościelnej i miłosierdzia chrześcijańskiego oraz nowe idee filantropijne. Wtedy to opiekę zaczęto pojmować jako czysto socjalny obowiązek państwa w stosunku do swoich obywateli. Można stwierdzić, że koniec XVIII wieku stanowił wyraźną cezurę, okres przejściowy między kościelnymi na ogół szpitalami specjalizującymi się przede wszystkim w opiece nad biednymi a szpitalami nowego typu, których główną funkcją było leczenie.

Analizując treści poruszane $\mathrm{w}$ pracy, łatwo wychwycić słowa czy pojęcia kluczowe, tak zwane dominanty: ubóstwo, miłosierdzie, opieka społeczna, szpitale, dobroczynność, szpital. Jest to konglomerat różnych terminów, lecz ze sobą integralnie związanych, wzajemnie się przenikających i tworzących główną oś, wokół której koncentruje się cała problematyka książki. Dzięki nim można obserwować dwa procesy - zjawiska, bardzo długo rozłożone w czasie: pierwszy - przechodzenia miłosierdzia w opiekę społeczną, oraz drugi - przekształcania się szpitala, dawniej klasycznego przytułku, w lecznicę. Z omawianych przez Autora ponad dwóch tysięcy lat dziejów opieki i dobroczynności można wysunąć jeszcze jeden wniosek, mianowicie, że ubodzy, ubóstwo, tak jak choroba, starość, stale towarzyszyło i towarzyszy ludzkości przez dzieje, co najwyżej przyjmuje różne rozmiary i formy. 
Publikacja posiada uniwersalny, interdyscyplinarny, wręcz humanitarny wymiar i adresowana jest do bardzo szerokiego grona odbiorców. $\mathrm{Z}$ pewnością mocno wpisuje się $\mathrm{w}$ badania $\mathrm{z}$ zakresu historii wychowania, której zadaniem jest również gromadzenie i rozwijanie wiedzy historycznej z zakresu opieki międzyludzkiej. Działalność opiekuńcza zawsze miała znaczenie wychowawcze, w związku z tym publikacja ta z pewnością powinna zainteresować szerokie grono historyków wychowania. Ponadto służy ona poznaniu ważnego aspektu historii społecznej czy historii Kościoła. Od strony praktycznej praca ta może zainteresować osoby związane z opieką społeczną czy socjalną, ukazując sprawdzone rozwiązania stosowane w przeszłości w opiece nad potrzebującymi. Zainteresuje też na pewno środowiska wolontariatu czy stawiającego sobie coraz ambitniejsze cele Caritasu. 